\title{
PATTERNS OF INFESTATION BY CHIGGER MITES IN FOUR DIURNAL LIZARD SPECIES FROM A RESTINGA HABITAT (JURUBATIBA) OF SOUTHEASTERN BRAZIL
}

\author{
CUNHA-BARROS, M., ${ }^{1}$ VAN SLUYS, M., ${ }^{1}$ VRCIBRADIC, D., ${ }^{1,2}$ \\ GALDINO, C. A. B., ${ }^{1}$ HATANO, F. H. ${ }^{1}$ and ROCHA, C. F. D. ${ }^{1}$ \\ ${ }^{1}$ Setor de Ecologia, Instituto de Biologia, Universidade do Estado do Rio de Janeiro, UERJ, \\ CEP 20550-013, Rio de Janeiro, RJ, Brazil \\ ${ }^{2}$ Pós-graduação em Ecologia, Departamento de Zoologia, Instituto de Biologia, \\ Universidade Estadual de Campinas, UNICAMP, CEP 13081-970, Campinas, SP, Brazil \\ Correspondence to: Carlos F. D. Rocha, Setor de Ecologia, Instituto de Biologia, Universidade do \\ Estado do Rio de Janeiro, UERJ, Rua São Francisco Xavier, 524, Maracanã, \\ CEP 20550-013, Rio de Janeiro, RJ, Brazil, e-mail: cfdrocha@uerj.br \\ Received Dezember 4, 2001 - Accepted May 13, 2002 - Distributed August 31, 2003
}

\begin{abstract}
We studied the parasitism by larvae of the chigger mite Eutrombicula alfreddugesi on the lizard community of Restinga de Jurubatiba, Rio de Janeiro State, Southeastern Brazil. We investigated the patterns of infestation (prevalence and intensity) of chigger mites in four sympatric lizards: Tropidurus torquatus, Mabuya agilis, M. macrorhyncha and Cnemidophorus littoralis. All lizards collected were checked for the presence of mites, which were counted under stereomicroscope. We tested the relationship between intensity of infestation and lizard body size for each species using regression analysis. The prevalences and mean intensities (+ one standard deviation) of infestation on each host species were, respectively: $100 \% ; 86.4+94.6$ in T. torquatus $(\mathrm{n}=62) ; 100 \% ; 20.9+9.3$ in M. agilis $(\mathrm{n}=$ $7) ; 100 \% ; 11.1+13.1$ in M. macrorhyncha $(\mathrm{n}=12)$; and $95.2 \% ; 19.1+16.8$ in C. littoralis $(\mathrm{n}=21)$. Only for $C$. littoralis did body size significantly affect the intensity of infestation $(r=0.27, p=0.02)$. For all lizard species, the body parts where chiggers occurred with the highest intensity were those of skin folds and joint regions.
\end{abstract}

Key words: chigger mite, parasitism, lizard, restinga habitat.

\section{RESUMO}

\section{Padrões de infestação por ácaros em quatro espécies de lagartos diurnos em um ambiente de restinga (Jurubatiba) no Sudeste do Brasil}

Nós estudamos o parasitismo por larvas do ácaro Eutrombicula alfreddugesi na comunidade de lagartos da Restinga de Jurubatiba, no Estado do Rio de Janeiro, Sudeste do Brasil. Nós investigamos os padrões de infestação (prevalência e intensidade) desse ácaro em quatro lagartos simpátricos: Tropidurus torquatus, Mabuya agilis, M. macrorhyncha e Cnemidophorus littoralis. Todos os lagartos coletados foram examinados para verificar a presença de ácaros, os quais foram contados sob microscópio estereoscópico. Nós testamos a relação entre a intensidade de infestação e o tamanho do corpo para cada espécie de lagarto, usando análise de regressão. As prevalências e intensidades médias de infestação (+ 1 desvio-padrão) por espécie hospedeira foram, respectivamente: $100 \% ; 86,4+94,6 \mathrm{em}$ T. torquatus $(\mathrm{n}=62) ; 100 \% ; 20,9+9,3 \mathrm{em}$ M. agilis $(\mathrm{n}=$ 7); $100 \% ; 11,1+13,1 \mathrm{em}$ M. macrorhyncha $(\mathrm{n}=12) ;$ e 95,2\%; 20,1 + 16,7 em C. littoralis $(\mathrm{n}=21)$. Somente em C. littoralis o tamanho corpóreo influenciou significativamente a intensidade de infestação $(\mathrm{r}=0,27$, $\mathrm{p}=0,02$ ). Para todas as espécies de lagarto, as partes do corpo onde os ácaros ocorreram com maior intensidade foram as áreas de dobras de pele e regiões axilares.

Palavras-chave: ácaro, parasitismo, lagarto, restinga. 


\section{INTRODUCTION}

In Brazil, studies on ectoparasitic mites have been mainly of veterinary interest and concerned only the list of ectoparasite species occurring in a particular place in a given host species. Conversely, there is comparatively little information regarding the ecology of these ectoparasites. In Brazil, the few studies concerning ecological aspects of chigger mites and their hosts have been mainly on small mammals (Gettinger, 1992; Martins-Hatano, 2000; Bittencourt \& Rocha, 2002) and reptiles (Cunha-Barros \& Rocha, 1995, 2000; Pinto, 1999; Vrcibradic et al., 2000).

Previous studies showed that many lizard populations in different environments, including restinga habitats, are parasitized by trombiculid mites (Cunha-Barros \& Rocha, 1995, 2000; Pinto, 1999; Vrcibradic et al., 2000). Restingas are open xeric environments, often densely populated by different lizard species (Araújo, 1984; Rocha, 2000). In restingas, most lizard species are infested by the trombiculid mite Eutrombicula alfreddugesi (CunhaBarros \& Rocha, 1995, 2000; Rocha et al., 2000). Thus, restingas are appropriate habitats to study some ecological parameters of ectoparasitsm by chigger mites in lizards. Although many lizard species may live sympatrically in restingas, the extent to which they are parasitized by those mites may be specific, resulting in differences in the infestation patterns depending on the host species involved (CunhaBarros \& Rocha, 2000).

At the restinga of Jurubatiba, in northern Rio de Janeiro State, four species within the lizard community are relatively abundant (Tropidurus torquatus, Tropiduridae; Mabuya agilis and M. macrorhyncha, Scincidae; Cnemidophorus littoralis, Teiidae) and they overlap extensively in activity period and habitat use (Hatano et al., 2001). Preliminary samples indicated that those four species were usually infested by the chigger mite Eutrombicula alfreddugesi. As a result, the knowledge of infestation patterns in these sympatric lizard species may be elucidative to learn how a parasite species may affect different sympatric hosts.

In this paper we investigate the patterns of infestation [prevalence and intensity; sensu Bush et al. (1997)] of the chigger mite E. alfreddugesi in four sympatric and syntopic lizards at the Restinga de Jurubatiba, especifically adressing the following questions: $i$ ) to which extent is $E$. alfreddugesi prevalent in each of the lizard species? ii) how does intensity of infestation differ among these hosts? iii) within species, is there a relationship between host body size and rate of infestation? iv) which is the preferred microhabitat of the chigger mite on the body of each host species? v) which is the index of discrepancy of E. alfreddugesi in the host's populations?

\section{MATERIAL AND METHODS}

\section{Study area}

The study was carried out at the restinga of Jurubatiba in an area adjacent to the Cabiúnas Lagoon ( $\left.22^{\circ} 16^{\prime} \mathrm{S} ; 41^{\circ} 41^{\prime} \mathrm{W}\right)$, Carapebus municipality, in northern Rio de Janeiro State, Brazil. The study area is located approximately $15 \mathrm{~km}$ north of Macaé city. Restingas are open sand-dune habitats, which occur along most of the Brazilian coastline (Eiten, 1992), and are characterized by predominantly scrubby and herbaceous xerophilic vegetation adapted to high salinity (Suguio \& Tessler, 1984). Annual rainfall in the area of Jurubatiba averages $1164 \mathrm{~mm}$ with a seasonal pattern. Mean monthly rainfall ranges from $41 \mathrm{~mm}$ in winter to $189 \mathrm{~mm}$ in summer (Henriques et al., 1986). Mean temperature in the area varies from $29.7^{\circ} \mathrm{C}$ in January to $20.0^{\circ} \mathrm{C}$ in July, with annual average of $22.6^{\circ} \mathrm{C}$ (Henriques et al., 1986). For a comprehensive description of the area see Henriques et al. (1986) and Araújo et al. (1998).

\section{Collecting methods and analysis}

We collected specimens of four lizard species within the lizard community in the restinga of Jurubatiba, Macaé, Rio de Janeiro State: Tropidurus torquatus; Cnemidophorus littoralis, Mabuya agilis and M. macrorhyncha.

Lizards were collected during March 1999 using air rifles, rubber bands, a noose, and gluetraps. Collections were made during a single month of the year to factor out possible seasonal effects on chigger infestation patterns. Lizards not promptly killed in the field were transferred to a plastic bag and euthanized with ether. After collection, lizards were weighed using a Pesola spring balance (to the nearest $0.2 \mathrm{~g}$ ) and measured in their snout-vent length (SVL) using a digital caliper (to the nearest $0.1 \mathrm{~mm}$ ). In the field, the lizards were fixed in $10 \%$ formalin in order to immediately kill the chigger mites before they could detach from the hosts' 
bodies. Lizards were preserved in white absorbant paper imbibed in formalin to check if any chigger mite (easy to see due to its red colour) detached from the lizard's body. Despite adopting this routine, our laboratorial observations indicated that the chigger mites do not detach from their sites of infestation in preserved lizards even after one year or more.

In the laboratory, each lizard's body was completely and carefully checked for mites under stereomicroscope. We counted the number of chigger mites infesting each region of the lizard body, in order to identify the preferred sites of infestation [i.e. those with the highest infestation intensities; for more details see Cunha-Barros \& Rocha (2000)].

We tested the relationship between intensity of infestation and lizard body size for each species using Regression Analysis (Zar, 1984). We tested for differences between lizards species in chigger prevalence using the Z-test for proportions (Zar, 1984). To test for differences in infestation intensity between lizard species we used One-Way Analysis of Variance (ANOVA), unless the distribution deviated from normality (verified by the Normal Distribution Goodness-of-Fit test), in which case we used the Mann-Whitney test (Siegel, 1975). We measured chigger mite aggregation in each lizard species using the index of discrepancy (Poulin, 1996):

$$
\mathrm{D}=1-[2(\mathrm{n}) / \mathrm{xN}(\mathrm{N}+1)]
$$

in which $n$ is total number of the parasites in all hosts, $\mathrm{N}$ is number of all hosts and $\mathrm{x}$ is the mean abundance.

\section{RESULTS}

All four lizard species studied were infested by the chigger mite Eutrombicula alfreddugesi but the rate of infestation varied greatly among species (Table 1). Only Cnemidophorus littoralis did not have all individuals parasitized. Tropidurus torquatus had the highest mean intensity of infestation, followed by Mabuya agilis, C. littoralis and M. macrorhyncha. Mean intensity of infestation did not differ statistically between any of the lizard species studied (C. littoralis and M. agilis: $\mathrm{F}_{1,26}=$ $0.07, \mathrm{p}=0.79 ;$ C. littoralis and $M$. macrorhyncha: $\mathrm{F}_{1,31}=2.01, \mathrm{p}=0.17 ;$ M. agilis and M. macrorhyncha: $\left.\mathrm{F}_{1,17}=2.98, \mathrm{p}=0.10\right)$. Similarly, prevalence did not differ $(\mathrm{p}>0.05)$ between lizard species in the community, except between Cnemidophorus littoralis and Tropidurus torquatus $(\mathrm{Z}=-1.73, \mathrm{p}=0.04)$.

The relationship between the intensity of infestation and lizard body size was significant only for Cnemidophorus littoralis $(\mathrm{r}=0.27, \mathrm{p}=0.02$, $\mathrm{n}=21$ ). For the other lizard species, body size did not explain infestation intensity (Tropidurus torquatus: $\mathrm{r}=0.04, \mathrm{p}=0.14, \mathrm{n}=59 ;$ Mabuya agilis: $\mathrm{r}=0.27, \mathrm{p}=0.23, \mathrm{n}=7 ;$ M. macrorhyncha: $\mathrm{r}=0.12$, $\mathrm{p}=0.26, \mathrm{n}=12$ ).

The index of discrepancy of Eutrombicula alfreddugesi distribution varied among host species, being highest in $C$. littoralis $(\mathrm{D}=0.91)$, decreasing steadily in $M$. macrorhyncha $(\mathrm{D}=0.85), M$. agilis $(\mathrm{D}=0,75)$ and being considerably lower in $T$. torquatus $(\mathrm{D}=0.03)$.

TABLE 1

Prevalence and mean intensity of infestation of the chigger mite Eutrombicula alfreddugesi in four lizards species of the Restinga de Jurubatiba, Rio de Janeiro State.

\begin{tabular}{|l|c|c|}
\hline & Prevalence (N) & Mean intensity \\
\hline Tropidurus torquatus & $100 \%(62)$ & $86.39+94.64$ \\
\hline Cnemidophorus littoralis & $95.2 \%(21)$ & $20.05+16.66$ \\
\hline Mabuya agilis & $100 \%(7)$ & $20.86+9.28$ \\
\hline Mabuya macrorhyncha & $100 \%(12)$ & $11.08+13.12$ \\
\hline
\end{tabular}


For all lizard species, in general, the body portions with highest intensity of infestation were those of skin folds and joint regions, especially the anterior armpits (Table 2). Those were the chiggers' preferential sites of infestation in all host species, except $C$. littoralis. In this latter species, mean infestation intensity was slightly higher on the groin and tail regions.

\section{DISCUSSION}

All lizards species studied in this community had high prevalence of Eutrombicula alfreddugesi (ca. 100\%), demonstrating that chiggers use indiscriminately all four lizard species as hosts. However, the mean infestation intensity and the mean infestation abundance were higher in T. torquatus than in the other lizard species.

TABLE 2

Mean abundance of the chigger mite Eutrombicula alfreddugesi on each site of the body for each lizard species studied.

\begin{tabular}{|c|c|c|c|c|}
\hline & $\begin{array}{c}\text { Tropidurus } \\
\text { torquatus }\end{array}$ & $\begin{array}{c}\text { Mabuya } \\
\text { agilis }\end{array}$ & $\begin{array}{c}\text { Mabuya } \\
\text { macrorhyncha }\end{array}$ & $\begin{array}{c}\text { Cnemidophorus } \\
\text { littoralis }\end{array}$ \\
\hline LGR & $7.24 \pm 14.08)$ & - & - & $0.24 \pm 0.77$ \\
\hline RGR & $8.11 \pm 16.14$ & - & - & $0.14 \pm 0.65$ \\
\hline LAA & $24.31 \pm 24.38$ & $9.43 \pm 6.42$ & $3.83 \pm 3.51$ & $2.09 \pm 4.28$ \\
\hline RAA & $18.73 \pm 20.95$ & $8.71 \pm 8.86$ & $6.17 \pm 7.80$ & $0.81 \pm 1.08$ \\
\hline LF & $0.17 \pm 0.86$ & - & - & - \\
\hline RF & $0.16 \pm 0.66$ & - & - & - \\
\hline LAF & $4.00 \pm 6.06$ & - & - & $0.57 \pm 1.03$ \\
\hline RAF & $4.16 \pm 6.69$ & - & - & $0.48 \pm 1.21$ \\
\hline LG & $0.05 \pm 0.28$ & - & - & $4.57 \pm 2.01$ \\
\hline RG & - & $0.57 \pm 0.98$ & - & $0.43 \pm 9.87$ \\
\hline LH & $0.37 \pm 1.01$ & - & - & $0.81 \pm 1.69$ \\
\hline RH & $0.50 \pm 1.59$ & $1.00 \pm 2.24$ & - & $1.52 \pm 3.23$ \\
\hline V & $0.66 \pm 1.95$ & - & - & $0.76 \pm 1.73$ \\
\hline D & $0.87 \pm 3.21$ & - & - & $0.62 \pm 1.46$ \\
\hline VT & - & - & - & $3.57 \pm 4.92$ \\
\hline DT & $0.06 \pm 0.31$ & - & - & $0.57 \pm 2.40$ \\
\hline CL & - & - & - & - \\
\hline OE & $3.29 \pm 5.09$ & - & - & - \\
\hline OD & $4.77 \pm 6.94$ & - & - & - \\
\hline D & -19 & - & - & \\
\hline
\end{tabular}

D - dorsal region; V - ventral region; LGR - left gular region; RGR - right gular region; LF - left foreleg; RF right foreleg; LAA - left anterior armpit; RAA - right anterior armipt; LAF - left anti-femoral region; RAF - right anti-femoral region; LH - left hindleg; RH - right hindleg; LG - left groin; RG - right groin; DT - dorsal tail; VT ventral tail; $\mathrm{C}$ - cloaca. 
Cunha-Barros \& Rocha (2000), studying the parasitism by $E$. alfreddugesi in these four lizard species in another restinga locality (Barra de Maricá, some $180 \mathrm{~km}$ south of Jurubatiba) concluded that morphological and behavioural factors can affect chigger infestation rates. Scaling pattern is one morphological aspect, which greatly differs among these lizards: Tropidurus torquatus have imbricated and keeled scales, whereas in scincids and teiids the scales are less imbricated and smooth. The scalling pattern of $T$. torquatus may facilitate mite access and fixation on the integument, when compared to those of the other three lizards studied. Moreover, T. torquatus is a sedentary forager, spending more time motionless than moving around (e.g. Bergallo \& Rocha, 1994; Rocha, 1994); this may also facilitate the access of mite larvae to its body. Thus, we suggest that the movement rate of the host may play an important role in the rate at which lizard species are infested by chigger mites. Nevertheless, in a study of the diurnal activity of E. alfreddugesi in a temperate area, Clopton \& Gold (1993) noticed "larval activity was marked by dawn and late afternoon - early evening activity peaks and midday reduction in activity. Activity was present throughout the night at low levels". In their study the authors concluded that $E$. alfreddugesi activity levels seem to be limited by high and low temperatures, low humidity and high incidence of sunlight. Tropidurus torquatus is active all day at Jurubatiba from early morning, until late afternoon (Hatano et al., 2001). At midday, when temperature is high, this lizard usually remains inside bushes where sunlight incidence and air temperatures are lower. Such behavior may favor the high infestation rates by chigger mites in this lizard, but more studies are necessary to verify this. Cnemidophorus littoralis is active during the hottest hours of the day and regulates relatively high body temperatures (TeixeiraFilho et al., 1995; Hatano et al., 2001); thus, foraging mode and hourly activity of hosts may affect the rates of parasitism by chigger mites. The scincids are intermediate between tropidurids and teiids in hourly activity (Hatano et al., 2001), foraging mode (Vrcibradic \& Rocha, 1996; Rocha et al., 2000) and infestation rates (Cunha-Barros \& Rocha, 1995, 2000; this study), suggesting we need more studies to really evaluate the influence of foraging behavior and activity patterns on infestation rates by chigger mites on restinga lizards.
Eutrombicula alfreddugesi distribution among individuals, according to the index of discrepancy (Poulin, 1993), differed among lizard species at the Restinga de Jurubatiba: only in Tropidurus torquatus was chigger mite distribution more uniform; in the other three species the distribution was aggregated. According to Poulin (1996), "our ability to measure aggregation level depends to large extent on sample size, because heavily infected hosts are rare, they usually only occur in large samples and are absent from small samples". Whereas for T. torquatus our sample was reasonably large $(n=62)$, it was comparatively small $(n=7-21)$ for the remaining species; thus, the true aggregation for the teiid and the skinks might have been underestimated.

The most intensely infested portions of the hosts' bodies were the joint regions, especially the armpits. According to Cunha-Barros \& Rocha (2000) skin folds and joint regions may favor attachment of chigger mites to the lizard skin. Attachment and feeding are favored because such regions have reduced scales similar to small granules resulting in an area of soft tissue. Fold regions may additionally protect mites from the abrasive effects of environmental factors such as insulation, wind and friction against the substrate.

Host body size is usually an important variable influencing the rates of parasitism for a particular host taxon (Poiani, 1992), because larger hosts tend to have proportionally more infection and infestation sites suitable to parasites when compared to smaller hosts (e.g. Vogel \& Bundy, 1987; Ribas, 1995). According to our results, only in Cnemidophorus littoralis did intensity and abundance of infestation by $E$. alfreddugesi vary with lizard body size, suggesting that for the other species body size seems not to be an important factor affecting infestation levels by these mites. In the lizard community of the Restinga da Barra de Maricá, on the other hand, infestation rates were related to lizard body size only in T. torquatus, whereas in C. littoralis body size did not correlate with infestation intensity (CunhaBarros \& Rocha, 2000). Thus, more studies are necessary to assess the effect of host body size on mite infestation rates.

The four lizard species differed in their mite infestation patterns from conspecific populations studied at the restinga of Barra de Maricá (CunhaBarros \& Rocha, 2000). Lizards at Barra de Maricá had mean infestation intensities two to five times 
higher than at Jurubatiba, except for C. littoralis, whose infestation intensity was higher at Jurubatiba. Nevertheless, within-community differences in infestation patterns among species were about the same in both areas, with $T$. torquatus having the highest values, followed by $M$. agilis, whose values were about twice as high as those of M. macrorhyncha.

The greatest difference between the two areas was that, in Jurubatiba, C. littoralis and M. agilis had very similar infestation intensities, whereas in Barra de Maricá the latter was considerably more infested than the former. Also, the most parasitized body regions of $T$. torquatus in Jurubatiba were the anterior armpits, whereas in Barra de Maricá they were the gular skin folds (both regions bear mite pockets in this species; see Rodrigues, 1987). At Jurubatiba, mites were almost restricted to the anterior armpits of Mabuya spp., whereas at Barra de Maricá they were more widely distributed throughout the skink's bodies (though the anterior armpits were also the most heavily infested regions). In another M. macrorhyncha population studied by Vrcibradic et al. (2000) in an insular habitat, infestation by Eutrombicula was also concentrated on the anterior armpits and overall infestation rates were also lower than at Barra de Maricá and comparable to those of the present study.

Thus, it seems that in areas where chigger mites occur at lower densities they tend to be concentrated on the axillary region of lizard hosts, whereas in areas where they occur at higher densities they may be more widely distributed along the hosts' bodies. This may reflect the fact that the armpit microenvironment (which is highly favored by the mites) may be frequently "saturated" with mite larvae in localities with high densitites of Eutrombicula, so that other individuals have to attach to other, less favored regions of the lizard body. The anterior axillae of T. torquatus and Mabuya spp. have differentiated scalation, with reduced granular scales that may facilitate fixation by the chiggers (in T. torquatus, a double mite pocket is present on each armpit). In C. littoralis, on the other hand, scales of the axillary region are not different from those of the lateral and dorsal regions, which are granular but very small and with very little space between them.

Hence, this species was the only one in which mites were not clearly concentrated on the axillary region (but the axillae were still one of the three most infested body regions for the teiid). Although differences in sample sizes (samples from Barra de Maricá were considerably larger for all species) may have somewhat influenced the trends we discussed above, it seems likely that lizards in Jurubatiba are less heavily infested than at Barra de Maricá. So, we conclude that density of Eutrombicula populations may vary among different coastal areas in southeastern Brazil and those variations are apparently reflected on patterns of lizard ectoparasitism (particularly infestation intensity) by those mites.

Acknowledgments - This study is a portion of the results of the "Programa de Pesquisas Ecológicas de Longa Duração PELD/CNPq of SITE \# 05" developed in Restinga de Jurubatiba and supported by CNPq and part of the "Programa de Ecologia, Conservação e Manejo de Ecossistemas do Sudeste Brasileiro" and of the Southeastern Brazilian Vertebrate Ecology Project (Laboratory of Vertebrate Ecology), of the Setor de Ecologia, Instituto de Biologia, Universidade do Estado do Rio de Janeiro. Permission to collect the lizards was conceded by the Instituto Brasileiro do Meio Ambiente e Recursos Naturais Renováveis - IBAMA (Permit \# 096/99-DIFAS). This study was partially supported by research grants from the Conselho Nacional do Desenvolvimento Científico e Tecnológico (CNPq) (processes \# 300819/94-3, 461970/00-7 and 301117/95-0) and from the Fundação de Apoio à Pesquisa do Estado do Rio de Janeiro (FAPERJ) (processes \# E-26/170.385/97-APQ1).

\section{REFERENCES}

ARAúJO, A. F. B., 1984, Padrões de divisão de recursos em uma comunidade de lagartos de restinga, pp. 327-342. In: L. D. Lacerda, D. S. D. Araujo, R. Cerqueira \& B. Turcq (eds.), Restingas: origem, estrutura, processos. CEUFF, Niterói.

Araújo, D. S. D., Scarano, F. R., SÁ, C. F. C., KURTZ, B., ZALUAR, H. L. T., MONTEZUMA, R. C. M. \& OLIVEIRA, R. C., 1998, Comunidades vegetais do Parque Nacional da Restinga de Jurubatiba, pp. 39-62. In: F. A. Esteves (ed.), Ecologia das lagoas costeiras do Parque Nacional de Jurubatiba e do Município de Macaé, RJ. NUPEM/UFRJ, Macaé, RJ.

BERGALlO, H. G. \& ROCHA, C. F. D., 1994, Spatial and trophic niche differentiation in two sympatric lizards (Tropidurus torquatus and Cnemidophorus ocellifer) with different foraging tactics. Austr. J. Ecol., 19: 72-75.

BITTENCOURT, E. B. \& ROCHA, C. F. D., 2002, Spatial use of rodents (Rodentia: Mammalia) host body surface by ectoparasites. Braz. Journ. Biol., 62(3): 419-425.

BUSH, A. O., LAFFERTY, K. D., LOTZ, J. M. \& SHOSTAK, A. W., 1997, Parasitology meets ecology in its own terms: Margolis et al. revisited. J. Parasitol., 83: 575-583.

CLOPTON, R. E. \& GOLD, R. E., 1993, Distribuition and seasonal and diurnal activity patterns of Eutrombicula afreddugesi (Acari: Trombiculidae) in a forest edge ecosystem. J. Med. Entomol., 30: 47-53. 
CUNHA-BARROS, M. \& ROCHA, C. F. D., 1995, Parasitismo por ácaros Eutrombicula alfreddugesi (Trombiculidae) em duas espécies simpátricas de Mabuya (Sauria: Scincidae): o efeito do habitat na prevalência e intensidade parasitária, pp. 307-316. In: F. A. Esteves (ed.), Oecologia brasiliensis I: estrutura, funcionamento e manejo de ecossistemas brasileiros. IB/UFRJ, Rio de Janeiro.

CUNHA-BARROS, M. \& ROCHA, C. F. D., 2000, Ectoparasitism by chigger mites (Eutrombicula alfreddugesi: Trombiculidae) in a restinga lizard community. Ciência e Cultura, 52: 108-114.

EITEN, G., 1992, Natural Brazilian vegetation types and their causes. An. Acad. Bras. Ciênc., 64 (Suppl. 1): 35-65.

GETTINGER, D., 1992, Host specifity of Laelaps (Acari: Laelapidae) in Central Brazil. J. Med. Entomol., 29: 71-77.

HATANO, F. H., VRCIBRADIC, D., GALDINO, C. A. B., CUNHA-BARROS, M., ROCHA, C. F. D. \& VAN-SLUYS, M., 2001, Thermal ecology and activity patterns of the lizard community of the restinga of Jurubatiba, Macaé, RJ. Rev. Brasil. Biol., 61: 287-294.

HENRIQUES, R. P. B., ARAÚJO, D. S. D. \& HAY, J. D., 1986, Descrição e classificação dos tipos de vegetação da restinga de Carapebus, Rio de Janeiro. Revta. Brasil. Bot., 9: 173-189.

MARTINS-HATANO, F., 2000, Associações dos ácaros Lelapineos (Acari: Laelapidae) com roedores e marsupiais (Mammalia) da Ilha Grande, Angra dos Reis, RJ. Dissertação de Mestrado, Universidade do Estado do Rio de Janeiro, Rio de Janeiro, 72p.

PINTO, M. G., 1999, Ecologia das espécies de lagartos simpátricos Mabuya nigropunctata $e \mathrm{M}$. frenata (Scincidae), no cerrado de Brasília e Serra da Mesa. Dissertação de Mestrado, Universidade de Brasília, Brasília, 104p.

POIANI, A., 1992, Ectoparasitism as a possible cost of social life: a compartive analysis using Australian passerines (Passeriformes). Oecologia, 92: 429-441.

POULIN, R., 1993, The disparity between observed and uniform distributions: a new look at parasite aggregation. International J. Parasitol., 23: 937-944.

POULIN, R., 1996, Measuring parasite aggregation: defending the index of discrepancy. International J. Parasitol., 26: 227-229.

RIBAS, S. C., 1995, Parasitismo por nematóideos em lagartos da Restinga da Barra de Maricá, RJ. Dissertação de Mestrado, Universidade do Estado do Rio de Janeiro, Rio de Janeiro, 99p.
ROCHA, C. F. D., 1994, Introdução à ecologia de lagartos brasileiros, pp. 39-57. In: L. B. Nascimento, A. T. Bernardes \& G. A. Cotta (eds.), Herpetologia do Brasil, 1. PUC-MG, Belo Horizonte.

ROCHA, C. F. D., 2000, Biogeografia de répteis de restinga: distribuição, ocorrência e endemismos, pp. 99-116. In: F. A. Esteves \& L. D. Lacerda (eds.), Ecologia de restingas e lagoas costeiras. NUPEM/UFRJ, Macaé.

ROCHA, C. F. D., VRCIBRADIC, D. \& ARAÚJO, A. F. B., 2000, Ecofisiologia de répteis de restingas brasileiras, pp. 117-149. In: F. A. Esteves \& L. D. Lacerda (eds.), Ecologia de restingas e lagoas costeiras. NUPEM/UFRJ, Macaé.

RODRIGUES, M. T., 1987, Sistemática, ecologia e zoogeografia dos Tropidurus do grupo torquatus ao sul do rio Amazonas (Sauria, Iguanidae). Arq. Zool., São Paulo, 31: 1-230.

SIEGEL, S., 1975, Estatística não-paramétrica para ciências do comportamento. McGraw-Hill, São Paulo.

SUGUIO, T. \& TESSLER, M. G., 1984, Planícies de cordões litorâneos quaternários do Brasil: origem e nomenclatura, pp. 15-25. In: L. D. Lacerda, D. S. D. Araujo, R. Cerqueira $\&$ B. Turcq (eds.), Restingas: origem, estrutura, processos. CEUFF, Niterói.

TEIXEIRA-FILHO, P., RIBAS, S. C. \& ROCHA, C. F. D., 1995, Aspectos da ecologia termal e uso do habitat por Cnemidophorus ocellifer (Sauria, Teiidae) na restinga da Barra de Maricá, RJ, pp. 155-165. In: F. A. Esteves (ed.), Oecologia brasiliensis I: estrutura, funcionamento e manejo de ecossistemas brasileiros. IB/UFRJ, Rio de Janeiro.

VOGEL, P. \& BUNDY, D. A. P., 1987, Helminth parasites of Jamaican anoles (Reptilia: Iguanidae): variation in prevalence and intensity with host age and sex in population of Anolis lineatopus. Parasitology, 94: 399-404.

VRCIBRADIC, D. \& ROCHA, C. F. D., 1996, Ecological differences in tropical sympatric skinks (Mabuya macrorhyncha and Mabuya agilis) in southeastern Brazil. J. Herpetol., 30: 60-67.

VRCIBRADIC, D., CUNHA-BARROS, M. \& ROCHA, C. F. D., 2000, Natural history notes. Mabuya macrorhyncha. Ectoparasites. Herpetol. Rev., 31: 174-175.

ZAR, J., 1984, Biostatistical analysis. Prentice-Hall, Englewood Cliffs. 